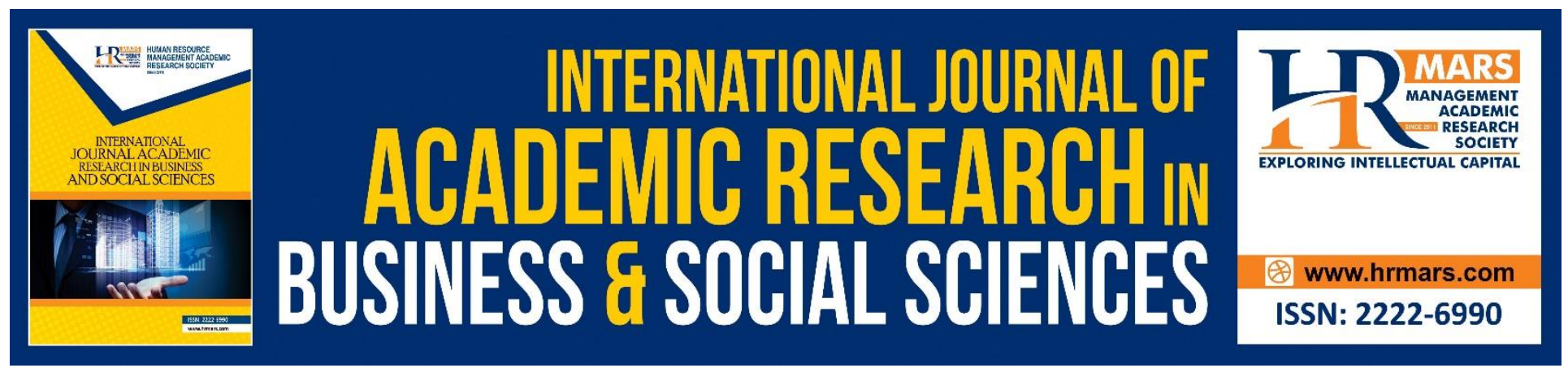

\title{
Intention of Restaurants' Patronage to Use Calories Information on Making Meal Selection
}

Puteri Nabihah Suhaimi, Lovelyna Benedict Jipiu

To Link this Article: http://dx.doi.org/10.6007/IJARBSS/v11-i13/8513

DOI:10.6007/IJARBSS/v11-i13/8513

Received: 12 November 2020, Revised: 19 December 2020, Accepted: 31 December 2020

Published Online: 20 January 2021

In-Text Citation: (Suhaimi \& Jipiu, 2021)

To Cite this Article: Suhaimi, P. N., \& Jipiu, L. B. (2021). Intention of Restaurants' Patronage to Use Calories Information on Making Meal Selection. International Journal of Academic Research in Business and Social Sciences, 11(13), 160-180.

\section{Copyright: (c) 2021 The Author(s)}

Published by Human Resource Management Academic Research Society (www.hrmars.com)

This article is published under the Creative Commons Attribution (CC BY 4.0) license. Anyone may reproduce, distribute, translate and create derivative works of this article (for both commercial and non-commercial purposes), subject to full attribution to the original publication and authors. The full terms of this license may be seen

at: http://creativecommons.org/licences/by/4.0/legalcode

Special Issue: Beyond 2021 and COVID-19 - New Perspective in the Hospitality \& Tourism Industry, 2021, Pg. 160 - 180

Full Terms \& Conditions of access and use can be found at http://hrmars.com/index.php/pages/detail/publication-ethics 


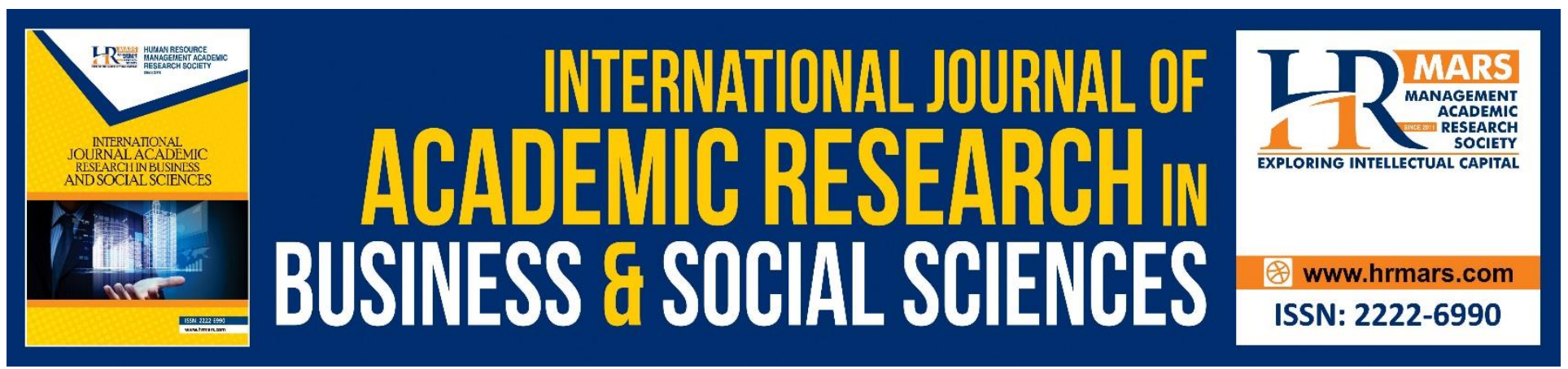

\title{
Intention of Restaurants' Patronage to Use Calories Information on Making Meal Selection
}

\author{
Puteri Nabihah Suhaimi, Lovelyna Benedict Jipiu
}

Faculty of Hotel \& Tourism Management, Universiti Teknologi MARA, Puncak Alam Campus, 42300, Selangor, Malaysia

\begin{abstract}
With the extending growth of restaurants' profiles and lifestyle urbanization that triggered the urge of patrons to eat out, food consumption of an individual has grown to rely on restaurant providers. Consequently, Malaysians aged 18 and above have been consuming extra calories than they supposed to on a daily basis. The fact that they habitually misjudged calories amount in outside foods explained how they set off tendency to over eat. Relating to restaurants' menus, calorie information is crucial as one of the desired guidance in assisting restaurant patrons to decide on meal selections. The relationship between Application of Theory of Planned Behavior elements that are attitudes, subjective norms and behavioral control were assessed between the intentions to make use of calories information in selecting meal at a restaurant. A self-completed questionnaires were distributed among 76 overall respondents through a convenience sampling method across Klang Valley. Findings discovered that attitudes, subjective norms and behavioral control proven to be statistically significant with intention to make use of calories information in restaurants' menu. The most effective influencer were, behavioral control, followed by subjective norms and attitudes. Evidently, it is part of public health priority to help consumers in making healthier choices when eating out, as postings of calorie information on menus may increase transparency on decision making.
\end{abstract}

Keywords: Restaurants, Calories Information, Theory of Planned Behavior, Attitude, Subjective Norm, Behavioral Intention

\section{Introduction}

\section{Eating Out of Restaurants' Patronage \& Calories Information}

While calorie-labeling practices are still a relatively new concept to be initiated worldwide, equipping public with reliable health-conscious information to support individual meal selections is considerably a valuable tool nowadays. According to Butler (2018), seeking for opportunity in helping consumers to make healthier choices when eating out is a substantial part of public health priority as calorie information posting on menus may increase transparency and enhance restaurants' accountability of the food that they served. Upon thinking of calories, most of us normally presumed the fat content in food. Aside from other health claims and nutritional content, calorie information 
comprises of related information that display the amount of energy in kilocalories (kcal) available within food and drinks. It is clarified by Ismail (2018) that if we constantly ingest extra energy than we required, one will suffer weight expansion; meanwhile if less energy is being consumed, fat, weight, and eventually muscle mass can be lost.

Looking into insight from another country, the Food and Drug Administration (FDA) of US rationalized nutritional facts label regulation that presents calorie content more noticeably within March 2014, whereby the arrangements of these marks have taken effect on restaurant menu items in May 2018 by which calorie content of every menu item is all written in standard font together with similar format used for item's price or name (Restrepo, Minor \& Peckham, 2018). Comparing that matter to Malaysia, the government does not have any implementation at the moment that provides education programs to restaurant operators and food service businesses on healthy eating even though eating out is prevailing in Malaysia, as clarified by head researcher Prof Dr Jean-Pierre Poulain, who is also the co-director of Taylor's Toulouse University Centre and the head of its Chair of Food Studies: Food, Cultures and Health through a reported news article on The Star Online in August 2014.

It was cleared up by the Institute for Public Health (2015) that about $50 \%$ of Malaysia's population is overweight. The leading lifestyle of Malaysians has been experiencing changes time after time, and by today eating away from home has evolved into one of the favored trends in Malaysia (Rahamat, 2019). Even though eating is intended to only suppress hunger, the consumption of food could also indicate the nutritional intake that someone has in a meal time. As mentioned by Hassan, Sade and Rahman (2018), Malaysians consumed more food than they should have. With fast advancement of food service businesses and the rise of the Malaysian general society in seeking for quick and convenient dietary life, a variety of food catering to different preferences are promptly accessible especially in urban areas. As consumers nowadays favor to dine outside of home due to unlimited food preferences available, their food intake would rely on the food provider. Chahal and Kamil (2017) justified that by dining outside, there could be a negative impact on the health of a person as the undeniable ongoing routine may trigger poor eating habits as the nutritional intake among consumers was taken lightly. This is because food produced outside of homes, precisely at restaurants, is expected to contain excessive amount of calories, carbohydrates, saturated fats and sugar (Rahamat, 2019).

To assist consumers in choosing food wisely, it is desirable to indicate nutritional information available in food (Kim, Kim \& Lim, 2015). This is because providing customers with the desired information via labels of calorie content at the point of purchase could be vital and obligatory for decision-making (Vijayakumaran \& Nur, 2018). According to these researchers, individuals who stumble upon calorie information on any menu of restaurants may discover them to be beneficial for their calorie consumption not only at restaurant settings, but also for later consideration at home or any other food service establishments.

Previous researchers have indicated that several variables of nutritional information focused typically on the attitude, knowledge and preferences but not much research has been done with relation to their intention in using calorie information in the scope of restaurants' food (Delvarani, 
Ghazali \& Othman, 2013). In order to fill up the gap, this study would evaluate the intention and acceptance of restaurant patrons to make use of calorie information by making their meal selections according to the theory of planned behavior and the construct involved. Banerjee and Shirley (2019) assured that individuals' intention to make use of calorie information is casted by their attitudes, social norms together with perceived behavioral control as the related constructs can be applied directly to the act of intention. The mentioned theory of planned behavior elements that are attitudes, subjective norms and behavioral control were discussed to extract the connection that they might retain in how they perceive the use of calorie information.

\section{Literature Review}

\section{Restaurant Industry \& Eating Out Patterns in Malaysia}

As indicated by Market Access Secretariat Canada Global Analysis Report (2014), their research concluded that there are five most popular food service profiles in Malaysia widely preferred by citizens, namely full-service restaurants, fast food chain, kiosks, cafés, street stalls or and home delivery services. In line with the attributes, potential customers surely capable in pampering their taste buds of preferences by fulfilling the demands offered by these restaurant profiles. Ajzen (2015) justified that food consumers nowadays are exposed to a wide range of choices throughout their day in which they are given the freedom to pick different options of food that may influence one's purchase decision. In the matter of restaurant availability experiencing rapid growth, customers encounter uncertainty deriving to their decision in having ranges of places to dine in.

The acknowledgement of fastest growing food service establishments here in Malaysia not only began reforming after the eating habits of Americans, but also due to the demands thriving and lifestyle evolving. Ali and Abdullah (2012) mentioned that with social transformation, eating out of home is a part of an individual deal in which can be segmented into working days and weekends of the week. It is almost a mundane routine for Malaysians regardless of age to consume out-of-home meals for any meal times of breakfast, lunch, dinner, and even supper meal. This is supported by Tan (2014) who stated that more than $64 \%$ of Malaysians dine at least one out-of-home meal per day in which among $36 \%$ of the remaining dine at home, and the last $12.5 \%$ have at least one meal that comes from outside. Hence, their food consumption rely the most on restaurant providers.

\section{Calories Labelling in Restaurant}

As clarified by Stran (2013), calorie-labeling is defined as the information of energy value food that is displayed on the menu of meal selections at particular restaurants. Meanwhile in Malaysia, the conduct of calorie-labeling is limited regardless of the type of restaurant profiles involved. This is due to no mandatory policy related to menu-labeling for food service industry in guiding customers to make healthier choices when consuming meals out of home (Rahamat, 2019). At present time, only a few of voluntary restaurants referred to voluntary guidelines in providing nutritional information, specifically fast food chains and full service restaurants. Consequently, resolved by Ministry of Health (2016), the implementation of calorie information as part of a menu label in various restaurants within Malaysia is included in the National Plan of Action for Nutrition of Malaysia III 2016-2025. It is mentioned by Block and Roberto (2015) that a gradual exposure of calorie information in restaurants to the public may escalate awareness of referring calories, discourage 
eating out, and encourage eating less, which together would result in an alteration of social norms when it comes to ordering meals.

Respectively, everyone has a different need of energy as the usage of energy would vary depending on several factors such as age, size, height, sex, lifestyle, and overall general health (Ismail, 2018). With more people engaging themselves in eating out-of-home meals, they tend to underestimate the calorie content of meals, especially large meals (Rettner, 2013). By looking through this matter from an economic outlook, restaurants are acknowledged as the typical example whereby consumers accomplish decisions based on less information (Blanding, 2011). It is clarified by Block and Roberto (2015) that without proper menu labels, the desired calorie information of menu items available at a restaurant was a hassle to comprehend. Calorie-labeling is intended to reveal the calorie information sharing that is displayed at the point of purchase which could be seen directly by the customers. In accordance to research to date, Malaysian restaurant patrons conveyed positive perceptions towards the practice of menu-labeling in a way that if they were to be provided with them, the intention to make use of its availability is increasing (Delvarani, Ghazali, \& Othman, 2013; Din, Zahari, \& Sharif, 2017). This is because assisting customers with appropriate calorie information label could play a role to assist customers in electing a healthier meal selection.

\section{The Theory of Planned Behavior}

The Theory of Planned Behavior (TPB) is established as a variables model that can integrate the intention of customers to make use of calorie information as part of their decision-making as conversed by Ajzen and Driver (1991), described that the frames of thought toward the behavior that is being anticipated to conduct. This is because performance of a behavior is decided by an individual's intention to proceed with it, whereby it can be determined by three known factors which are attitudes towards the behavior, subjective norms and perceived control over that (Kim, Kim \& Lim, 2015).

\section{Attitudes}

Attitudes towards behavior is characterized as the individual's conviction that may prompts certain results and perceived assessments or through alternate words, alludes to how much execution of behavior is adversely valued either positive or negative (Ajzen, 1991). Ajzen and Fishbein (1980) have revealed that a person's attitudes towards any item can be anticipated with a high level of precision from the knowledge of the person's belief about the mentality on the object and the assessment of these beliefs. If an individual agreed to the fact that perception related to calorie information could influence a better prospect, the attitude towards that practice would undeniably be positive. It is also stated by Zainol, Yahaya, Osman, Omar, Ramdan and Habidin (2018) that knowledge of calorie information and health consequences resulting from making selections of meals may impact the attitude positively. This is for the reason of improving customers' evaluation towards the restaurants' menu through the revelation of healthful information (Kim, Ham, Yang \& Choi, 2013).

Consequently, the attitudes may be comprehended as the lead to sway the intended behavior as the decision was made purely based on personal evaluation acts. As professed by Alam and Sayuti (2011), attitude belongs to the level of extent that an individual devours in terms of favorable or 
unfavorable manners. Acknowledging consequences of healthy diet and benefits of practicing calorie information of menus through local advertisement may create highly favorable attitudes in generating intentions to make use of the important information (Delvarani, Ghazali \& Othman, 2013). The beliefs and learning held by individuals about an item or exact qualities of the offering is what the intellectual part alludes to (Daghbashyanm, 2013). Evaluations take place in minds of an individual which will eventually influence their attitude by how they perceive calorie information as a matter to consider in meal selections.

\section{Subjective Norm}

A subjective norm is defined as dealing with the influence of social environment on behavior (Kholoud, 2009). It can also be perceived as the social pressure to meet the terms of expectations of engaging in the individual's intention in performing or not performing an intended behavior (Delvarani, Ghazali \& Othman, 2013). Even though not everyone is interested in using calorie information to aid their meal selections at restaurants, the probability can increase if their closest cliques tend to do so.

A recent study by Rahamat (2019) justified that views and opinions of groups or individuals such as friends or family members possess the sturdiest impact on the intention to make use of calorielabeling in restaurants. This is because every word of mouth that is spoken by the closest and most reliable companions may impose huge control on the decisions made by an individual. It provides an individual with better assurance to conduct a certain act of behavior based on how their surrounding will perceive that matter. On the other hand, with social expectations wedged in between that could trigger an individual to perform badly, the individual can be expected to not do as well as the former (Armitage \& Conner, 2001). Individuals may decide to pursue an intention if there is a verbal cue for it.

Individuals apparently do not only perform behavior under social pressure but also with the subjective norm providing them information about the appropriateness of behavior for them to consider (Jager, 2000). Those who accept their parents and friends opinions in which they should make use of the posted calorie information had higher intentions than those with opposite perceptions (Stran, 2013). Since an individual's concept of behavior refers to personal experiences, together with secondhand information from acquaintances' and friends' past experiences, a normative belief would surely affect their decision-making (Kim, Ham, Yang \& Choi, 2013). Therefore, this study includes subjective norms as one of the constructs to assess customers' intention in making use of calorie information to decide on their meal selections.

\section{Behavioral Control}

Perceived behavioral control is determined by beliefs of control as well as perceived power over the behavior, referring to an individual's perception (Ajzen \& Driver, 1991). According to Ramayah, Lee and Lim (2012), they assured that the capacity of an individual to embrace the behavior is under the supposition that the individual acts in a rational way while considering the implication of his or her activities. In relation to making use of calorie information to conduct meal selections, there are two aspects in reliance with this behavioral control in which how much the person has control over 
their behavior and how self-assured the person may feel in performing the anticipated behavior (Delvarani, Ghazali \& Othman, 2013). If one thinks that his action is reliable enough to proceed with, only then will they engage with the action up to the level that they have control of. Although there were reported research on how perceived behavioral control may be affected, prior research conducted by Jun and Arendt (2016) stated that perceived behavioral control has positively affected healthy eating intentions and behavior due to the positive belief they had. Appealed by Kim, Ham, Yang and Choi (2013), internal factors related to abilities or knowledge and external factors inclusive of time, opportunity were usually determine behavioral control. Those who have a high degree of perceived behavioral control would produce greater intention in making use of calorie information displayed at restaurants (Stran, 2013). The more control an individual has on using calorie information in making meal selections, the more probable he or she will do so (Delvarani, Ghazali \& Othman, 2013).

\section{Intention in Making Use of Calories Information}

Finally, intention to perform a behavior is dependent on the theory attributes which are attitudes, subjective norms, and perceived control of the behavior (Ajzen, 1991). Banerjee and Shirley (2019), emphasized that TPB is regularly used to generate the intention of certain act as the desire of it can be formed by the mentioned attributes. Intention explains that there is a possibility to proceed with an anticipated desire. It influences the act of performance that will be done by leading the prompted instinct, whereby in this study these three construct variables will affect the intention of making use of calorie information at restaurant settings. Accordingly, customers have a tendency to conduct actual behavior when intentions to perform it become stronger (Kim, Ham, Yang \& Choi, 2013). In this study, if patrons are expected to perform specific behavior such as using calorie information on restaurant menus to create wiser healthy choices, it can be foreseen that they will proceed with the act once prompted with opportunity (Stran, 2013).

\section{Methodology}

Indicating cross-sectional correlational field of study, the data is collected from restaurant patronage who are familiar with calorie information based on the three independent variables (attitudes, subjective norms and behavioral control) with a dependent variable (intention to make use of calories labeling) to discover out the relationship between those variables. In this study, a nonprobability sampling design was chosen as it is impossible to comprise every targeted subject because population is practically subject to limitations (Etikan, Musa \& Alkassim, 2016). Bearing the circumstances in mind, there is an inability determinant of the exact patronage of restaurants since it cannot be differentiated from the whole population of Malaysia. Therefore, a representative sample that included the members of the population in making important decisions about the population was determined.

Since the unit analysis of this study involves restaurant patrons who consumed out-of-home meals and are familiar with calorie information, Klang Valley is the most relevant area of cosmopolitan to be chosen, alongside with the rise of urbanization that is bringing in lifestyle changes as clarified by Ali \& Abdullah (2012). Looking at the urbanization of the Federal Territory of Kuala Lumpur, Petaling Jaya and Shah Alam, there is an impact on the population's trend to eat out on a 
daily basis (Lee, Lee, Chua \& Han, 2017). These area undergo a spurt of development with high demands for not only good food, but also for restaurants to offer a plethora of variations of healthy, nutritious and scrumptious food that trigger the desire for food among consumers (Chahal \& Kamil, 2017). For this study, the convenience sampling method was implemented to conclude the representation of restaurant patrons' selections depending on easy accessibility, geographical proximity, readiness at expected time as well as their willingness to participate (Etikan, Musa \& Alkassim, 2016). Aligned with previous study by Delvarani, Ghazali and Othman (2013), respondents for this scope of study were restricted to be within 18 years old and above due to financial independency and should also possess basic calorie knowledge.

Alongside a huge population being preferred for data collection of this research, required sample size were declared. Referring to the rule of thumb proposed by Tabachnick and Fidell (2013), the desired sample size will either rely on the number of issues, preferred power, alpha number, amount of predictors or targeted effect sizes. As for this research, a formula of both researchers relating to the number of predictors which is $N \geq 50+8 m$ is used for calculation whereby $m$ is the amount of independent variables involved. Thus, $N \geq 50+8(3)=74$ indicates the number of respondents required for this study. Upon comparison with Sample Size Table of Cohen (1992), which are 74 and 76 respectively with the difference of just 2, the sample size of this study is accepted to proceed with 76. This is supported by Roscoe (1975) in which he proposed that a sample size larger than 30 and less than 500 is appropriate enough for most researches. Sekaran (2006) declared that with an extensively wide sample size, we are prone to be certain of significant relationships found among populations when in fact they may not be legitimate.

A total of 51 questionnaire items allocated through five sections of closed ended questions were used for data collection. In gathering the data needed, potential respondents were approached and the aim of the survey was explained to them. Only after confirming their familiarity with calorie information, the set of questionnaires were personally given to them for them to answer. Both versions of Malay and English set of questionnaires are provided on Google Form upon preferential request. The alternative of using Google Form provide ability to avoid the issue of not receiving questionnaire data since the software requires every question to be answered before respondents can advance to the next section until the overall response was submitted. Additionally, electronic and online questionnaire is an easy and efficient way to gain data as the researcher only need to send an invitation link to complete the survey together with the benefit of its convenience as it would automatically process the survey, store the answers, and even provide online statistical analysis through its statistical software.

Upon data completion in which the sample of 76 was fully retrieved, a complete data was analyzed using the IBM Statistical Package for the Social Sciences, Windows Version 21.0 (SPSS 21.0). All predetermined tests such as the frequency distribution to test the socio-demographic variables and descriptive statistics (mean score and standard deviation) were used to test the consistency of the respondents' answers. In order to explore the total effect of independent variables on the dependent variable for this study, multiple regression analysis was conducted as this study has more than two independent variables (Nor, Noor, Ahmad, Khalid \& Ibrahim, 2017). Referring to Tabachnick 
INTERNATIONAL JOURNAL OF ACADEMIC RESEARCH IN BUSINESS AND SOCIAL SCIENCES

Vol. 11, No. 13, Beyond 2021 and COVID-19 - New Perspective in the Hospitality \& Tourism Industry. 2021, E-ISSN: 2222-6990 @ 2021 HRMARS

and Fidell (2013), multiple regression analysis enables a researcher to evaluate the relationship between one dependent variable (DV) and several independent variables (IVs).

\section{Result and Analysis \\ Socio-demographic Profiles}

With regard to gender distribution, out of 76 total respondents, $56.6 \%(n=43)$ of them were female and $43.4 \%(n=33)$ were male. It is apparent that majority of the respondents were female group. As clarified by Stran, Knol, Severt and Lawrence (2016), women are more interested to calories information on restaurants' menu as compared to men. Respondents with the age of 18 to 25 years old made up the greater portion of the results with $42.1 \%(n=32)$. The result is similar with study by Kwan, Pan, Maynard, McGuire and Park (2016) in which they found young adults whom aged between 18 and 29 years were prone to testimony as frequent users of menu labelling comparing to older participants. $63.2 \%(n=48)$ respondents of this study are single, comparing to only remaining $36.8 \%(n=28)$ are married. For the dimension of race background, majority of respondents are dominated by Malay respondents with $59.2 \%(n=45)$ and followed by Chinese respondents with $19.7 \%$ $(n=15), 14.5 \%(n=11)$ are Indian respondents and $6.6 \%(n=5)$ are those of Bumiputera. Findings of Delvarani, Ghazali \& Othman (2013) were justified that the study accumulates three races of Malay, Chinese and Indian that were $61.8 \%, 26.6 \%$ and $7.8 \%(n=395)$ in which distribution signifies tolerable ratio in Malaysia.

After all, 63.2\% ( $n=48$ ) out of 76 respondents are majority from those with degree of education level, $17.1 \%(n=13)$ master level, $14.5 \%(n=11)$ diploma level, $2.6 \%(n=2)$ with foundation level and $2.6 \%$ $(n=2)$ of doctorate level. As indicated by Green, Brown and Vachaspati (2014), educated individuals prone to adapt healthier behavior inclusive of likelihood to utilize newspaper, books or magazines for seeking health information. Furthermore, major groups with 38.2\% $(n=29)$ of respondents are from private sector employees, followed closely by $30.3 \%(n=23)$ of respondents that are higher institutions' students, $22.4 \%(n=17)$ of government servants, $6.6 \%(n=5)$ of self-employed and $2.6 \%$ $(n=2)$ are unemployed.

Regardless that, majority $38.2 \%(n=29)$ of the respondents conquer the most of all by selecting full service restaurants as their preferable restaurants followed next with $25.0 \%(n=19)$ choosing fast foods restaurant, $22.4 \%(n=17)$ picked café and $14.5 \%(n=11)$ by least selected food court. It is justified by Kiszko, Martinez, Abrams and Elbel (2014) that even though calories information can cater positive influence, effects may be likely to be unpredictable depending on varies kind of foods being offered. Among all, 40.8\% ( $n=31)$ dominating the respondents' group in which they eat out for 1 to 3 times a week on weekly basis, $17.1 \%(n=13)$ of respondents eat out approximately 2 times on daily basis in which $10.5 \%(n=8)$ eating out 3 times per day and $5.3 \%(n=4)$ of respondents that eat out only one time in a day. It is reported by Chahal and Kamil (2017) that frequent of eating out accordingly could bring negative impact to individuals' health due to this ongoing routine could prompt poor eating habits and shifting nutritional intake. Hence, 35.5\% ( $n=27)$ of respondents claimed that they were not sure about the healthy state of their overall food consumption, 30.3\% $(n=23)$ presumed their food consumption were acceptably healthy, $17.1 \%(n=13)$ testified that they prefer not to care, $11.8 \%$ $(n=9)$ of respondents agreed that their food consumption were just good. Rather than that, 3.9\% $(n=3)$ of respondents acknowledged that the health state of their food consumption are excellent meanwhile $1.3 \%(n=1)$ claimed as not bad. Through that analysis, Ambak, Tupang, Hasim, Salleh, 
Zulkafly, Salleh, Ahmad and Naidu (2018) stated that individual typically alert with any nutrient and dietary guidelines only when they are entitled to strict motivation in controlling their disease through food consumption.

On top of that, the majority figure of $22.4 \%(n=17)$ respondents sometimes refer to calories information on restaurants' menu followed by $19.7 \%(n=15)$ of respondents did refer but occasionally. With percentage of $18.4(n=14)$, respondents agreed that they frequently refer to calories information. Sharing same percentage, $14.5 \%(n=11)$ of respondents rarely and never do so respectively. Followed by $7.9 \%(n=6)$ and $2.6 \%(n=2)$, respondents usually and always respectively refer calories information on restaurant's menu in conducting meal selection. It is enlightened by Breck, Cantor, Martinez and Elbel, (2014) that likely, individual whom interested in nutrition knowledge and healthy eating habits were more susceptible to own more tendency in referring and making use of calories information.

Regarding reasons on considering calories on restaurants' selection, $47.4 \% \quad(n=36)$ of respondents clarified that they referred to calories information only because they curious to know the amount of calories for every menus offered. With $26.3 \%(n=20)$, respondents cleared up that they referred calories information on restaurants' menu to help them deciding better choices, $15.8 \%$ $(n=12)$ due to their traits of them being careful with their calories intake meanwhile only $10.5 \%(n=8)$ referred because of their unfamiliarity with restaurants' product quality. Aligned with study by Ambak, Tupang, Hasim, Salleh, Zulkafly, Salleh, Ahmad and Naidu (2018), potential reasons for this condition were due to their inadequate knowledge and ignorance to nutrient information in which they believed calories information were not essential to their health.

Lastly, upon asking on whether ability of a restaurant to provide calories information on menus determine their decision to eventually pick a restaurant to eat, $26.3 \%(n=20)$ of respondents agree to the fact, $19.7 \%(n=15)$ slightly agree and only $11.8 \%(n=9)$ strongly agree. Somehow, $19.7 \%(n=15)$ of respondents were neutral about the fact claimed followed by $17.1 \%(n=13)$ respondents were slightly disagree and $5.3 \%(n=4)$ disagree. This is due to a dispute made against calories labelling in which stating these information could lessen contentment of people against eating out as knowing calories information would restrain them to shift from their usual meal selection (Sturm, Huang, Tsang, Hiatt, Smart, Wright \& Wu, 2018).

\section{Descriptive Statistic Results \\ Attitudes}

Attitudes is one of the TPB Element that possess as the first independent variable entitled for this study. It is significantly necessary to understand how the attitude of patronage restaurants could affect the intention to make use of calories information in making their meal selection. Thus, results of the analysis retrieved for this aspect are presented in the following Table 1. 
INTERNATIONAL JOURNAL OF ACADEMIC RESEARCH IN BUSINESS AND SOCIAL SCIENCES

Vol. 11, No. 13, Beyond 2021 and COVID-19 - New Perspective in the Hospitality \& Tourism Industry. 2021, E-ISSN: 2222-6990 @ 2021 HRMARS

Table 1: The Mean and Standard Deviation Score of Attitudes

\begin{tabular}{|c|c|c|c|}
\hline No. & Items & Mean & SD \\
\hline 1. & $\begin{array}{l}\text { I believe using calorie information } \\
\text { posted on restaurant menus to make a } \\
\text { meal decision is beneficial. }\end{array}$ & 6.14 & 0.860 \\
\hline 2. & $\begin{array}{l}\text { I think it is useless for restaurants to } \\
\text { have calories information posted on } \\
\text { restaurants' menu. }\end{array}$ & 2.87 & 1.914 \\
\hline 3. & $\begin{array}{l}\text { I perceive that it is difficult to decide } \\
\text { for meal selection by having calories } \\
\text { information along with stated choices. }\end{array}$ & 4.18 & 1.622 \\
\hline 4. & $\begin{array}{l}\text { I never put calories information as } \\
\text { my priority that can affect me in selection } \\
\text { meal to have. }\end{array}$ & 4.01 & 1.645 \\
\hline 5. & $\begin{array}{l}\text { I do not mind even if the meal I end } \\
\text { up choosing appeared to be the menu } \\
\text { with high calories content. }\end{array}$ & 4.11 & 1.563 \\
\hline 6. & $\begin{array}{l}\text { I have no valid reasons to pick a } \\
\text { meal selection by referring to calories } \\
\text { statement. }\end{array}$ & 3.62 & 1.681 \\
\hline 7. & $\begin{array}{l}\text { I agree to the fact that perception } \\
\text { related to calories information shall } \\
\text { influence a better prospect of choices. }\end{array}$ & 5.68 & 1.061 \\
\hline 8. & $\begin{array}{l}\text { I think having knowledge of calories } \\
\text { information will resulted in positive } \\
\text { attitude to make use of calories } \\
\text { information in making meal selection. }\end{array}$ & 6.04 & 0.958 \\
\hline 9. & $\begin{array}{l}\text { I presume recognizing possible } \\
\text { health consequences will resulted in } \\
\text { positive attitude to make use of calories } \\
\text { information in making meal selection. }\end{array}$ & 5.99 & 0.887 \\
\hline 10. & $\begin{array}{l}\text { I believe the exposure of practicing } \\
\text { calories information of menus through } \\
\text { local advertisement may create high } \\
\text { favorable attitudes in generating } \\
\text { intentions to make use of the important } \\
\text { info. }\end{array}$ & 5.97 & 0.909 \\
\hline
\end{tabular}

\section{Subjective Norms}

Subjective norm is one of the TPB Element that own as the second independent variable entitled for this study. It is desirable to understand how the subjective norm of patronage restaurants could 
INTERNATIONAL JOURNAL OF ACADEMIC RESEARCH IN BUSINESS AND SOCIAL SCIENCES

Vol. 11, No. 13, Beyond 2021 and COVID-19 - New Perspective in the Hospitality \& Tourism Industry. 2021, E-ISSN: 2222-6990 @ 2021 HRMARS

affect the intention to make use of calories information in making their meal selection. Following Table 2 shows the results of this section obtained.

Table 2: The Mean and Standard Deviation Score of Subjective Norms

\begin{tabular}{|c|c|c|c|}
\hline No. & Items & Mean & SD \\
\hline 1. & $\begin{array}{l}\text { My parents think that I should make } \\
\text { use of calories information in settling for } \\
\text { meal selection at restaurants. }\end{array}$ & 4.53 & 1.637 \\
\hline 2. & $\begin{array}{l}\text { I have been raised to be cautious } \\
\text { with what I choose to eat. }\end{array}$ & 4.72 & 1.694 \\
\hline 3. & $\begin{array}{l}\text { I have friends and social circle that } \\
\text { consider calories information in making } \\
\text { choices on what to eat. }\end{array}$ & 5.03 & 1.479 \\
\hline 4. & $\begin{array}{l}\text { It is expected of me that I use } \\
\text { posted calorie information in restaurants. }\end{array}$ & 4.86 & 1.303 \\
\hline 5. & $\begin{array}{l}\text { I feel under social pressure to use } \\
\text { posted calorie information in restaurants } \\
\text { to select for a meal. }\end{array}$ & 4.21 & 1.636 \\
\hline 6. & $\begin{array}{l}\text { I would feel the urge to make better } \\
\text { choices in meal selection if I have people } \\
\text { close to me referring to calories } \\
\text { information as a lead in making decision. }\end{array}$ & 5.62 & 0.993 \\
\hline 7. & $\begin{array}{l}\text { I would be easily influenced by social } \\
\text { circle that encourage me to refer calories } \\
\text { information for my meal selection. }\end{array}$ & 5.49 & 1.000 \\
\hline 8. & $\begin{array}{l}\text { I would listen to people that are } \\
\text { important to me in deciding my meals } \\
\text { regardless the calories content. }\end{array}$ & 5.18 & 1.324 \\
\hline 9. & $\begin{array}{l}\text { I would value and choose the least } \\
\text { calories content meal suggestions offered } \\
\text { by someone I trusted. }\end{array}$ & 5.62 & 0.952 \\
\hline 10. & $\begin{array}{l}\text { People like me use calorie labelling in } \\
\text { restaurants to make menu choices. }\end{array}$ & 4.79 & 1.445 \\
\hline
\end{tabular}

\section{Behavioral Control}

This section comprises of last independent variables which is the behavioral control of restaurants' patronage. It is important to comprehend how the behavioral control of patronage restaurants could affect the intention to make use of calories information in making their meal selection. 
INTERNATIONAL JOURNAL OF ACADEMIC RESEARCH IN BUSINESS AND SOCIAL SCIENCES

Vol. 11, No. 13, Beyond 2021 and COVID-19 - New Perspective in the Hospitality \& Tourism Industry. 2021, E-ISSN: $2222-6990$ @ 2021 HRMARS

Table 3: The Mean and Standard Deviation Score of Behavioral Control

\begin{tabular}{|c|c|c|c|}
\hline No. & Items & Mean & SD \\
\hline \multirow[t]{2}{*}{1.} & I am confident that I could use & & \\
\hline & $\begin{array}{l}\text { calorie information in a restaurant to } \\
\text { make a healthy choice. }\end{array}$ & 5.99 & 0.945 \\
\hline \multirow[t]{2}{*}{2.} & I found it is easy for me to adapt & & \\
\hline & $\begin{array}{l}\text { using calorie information in a restaurant } \\
\text { to make a healthy choice. }\end{array}$ & 5.80 & 1.033 \\
\hline \multirow[t]{2}{*}{3.} & The decision to use calories & & \\
\hline & $\begin{array}{l}\text { information in a restaurant is based on the } \\
\text { amount of time I have. }\end{array}$ & 5.57 & 1.289 \\
\hline \multirow[t]{2}{*}{4.} & The decision to use calories & & \\
\hline & $\begin{array}{l}\text { information in a restaurant depends on } \\
\text { how hungry I am. }\end{array}$ & 4.95 & 1.469 \\
\hline \multirow[t]{2}{*}{5.} & The decision to use calories & & \\
\hline & $\begin{array}{l}\text { information in a restaurant is based on the } \\
\text { price of the menu items. }\end{array}$ & 5.24 & 1.384 \\
\hline 6. & $\begin{array}{l}\text { I feel better to be able selecting } \\
\text { healthier menu options for my meal. }\end{array}$ & 5.75 & 1.021 \\
\hline \multirow[t]{2}{*}{7.} & I would try to consider meal & & \\
\hline & $\begin{array}{l}\text { selection by making calories information as } \\
\text { my guidelines. }\end{array}$ & 5.75 & 0.940 \\
\hline \multirow[t]{2}{*}{8.} & I do not mind referring to calories & & \\
\hline & $\begin{array}{l}\text { information of my selected menu in } \\
\text { checking my calories consumption in a day. }\end{array}$ & 5.66 & 1.102 \\
\hline \multirow[t]{2}{*}{9.} & I have the opportunity to use calories & & \\
\hline & $\begin{array}{l}\text { information in restaurants before placing } \\
\text { my order. }\end{array}$ & 5.30 & 1.233 \\
\hline 10. & $\begin{array}{l}\text { I have a feeling that I cannot do } \\
\text { anything about how I decided my meal } \\
\text { selection every time visiting a restaurant. }\end{array}$ & 4.55 & 1.652 \\
\hline
\end{tabular}

Intention to Make Use of Calories Information

After the discussion of all independent variables have been done, the dependent variable which is intention of restaurants' patronage would be presented. 
INTERNATIONAL JOURNAL OF ACADEMIC RESEARCH IN BUSINESS AND SOCIAL SCIENCES

Vol. 11, No. 13, Beyond 2021 and COVID-19 - New Perspective in the Hospitality \& Tourism Industry. 2021, E-ISSN: 2222-6990 @ 2021 HRMARS

Table 4: The Mean and Standard Deviation Score of Intention

\begin{tabular}{|c|c|c|c|}
\hline No. & Items & Mean & SD \\
\hline 1. & $\begin{array}{l}\text { If nutrition or health information } \\
\text { were readily available in restaurants' } \\
\text { menu, I would use it in deciding what to } \\
\text { order. }\end{array}$ & 5.86 & 0.905 \\
\hline 2. & $\begin{array}{l}\text { My intention to consider enough } \\
\text { calories intake per meal are very high with } \\
\text { the availability of calories information. }\end{array}$ & 5.61 & 0.925 \\
\hline 3. & $\begin{array}{l}\text { I planned to use calorie information } \\
\text { in a restaurant before placing my order of } \\
\text { meal selection. }\end{array}$ & 5.68 & 0.996 \\
\hline 4. & $\begin{array}{l}\text { I want to make use of calories } \\
\text { information in helping my meal selection. }\end{array}$ & 5.75 & 0.911 \\
\hline 5. & $\begin{array}{l}\text { I intend to consume less calories } \\
\text { content meals whenever I visited a } \\
\text { restaurant. }\end{array}$ & 5.26 & 1.360 \\
\hline 6. & $\begin{array}{l}\text { I will make an effort to browse } \\
\text { through calories information before } \\
\text { deciding on what to eat. }\end{array}$ & 5.09 & 1.601 \\
\hline 7. & $\begin{array}{l}\text { The likelihood that I would rely on } \\
\text { calories information to proceed with my } \\
\text { meal are very high. }\end{array}$ & 5.32 & 1.191 \\
\hline 8. & $\begin{array}{l}\text { I plan to start consider my meal } \\
\text { selection by using calories information not } \\
\text { only when visited restaurant but also for } \\
\text { home meal. }\end{array}$ & 5.62 & 1.045 \\
\hline
\end{tabular}

\section{Multiple Regression Analysis}

In response to anticipate research hypothesis appropriately of this study, standard multiple regression were utilized between three of independent variable that are attitudes, subjective norms and behavioral control and dependent variable of intention.

Table 5: Regression Result Summary

\begin{tabular}{cccccc} 
Model & $\mathbf{R}$ & $\begin{array}{c}\mathbf{R} \\
\text { Square } \\
\mathbf{R}^{\mathbf{2}}\end{array}$ & $\begin{array}{c}\text { Adjusted } \\
\mathbf{R} \text { Square }\end{array}$ & $\begin{array}{c}\text { Std } \\
\text { Error of the } \\
\text { Estimate }\end{array}$ & F Change \\
\hline $\mathbf{1}$ & 0.758 & 0.575 & 0.557 & 0.45112 & $32.434^{* * *}$ \\
\hline
\end{tabular}

In this study, $R^{2}$ value generated is 0.575 . Since this $R^{2}$ value interpretation is expressed as percentage manner, the value of 0.575 explained that 57.5 percent of the variation in intention can be explained by the attitudes, subjective norms and behavioral control. Through the multiple regression results analysis, results indicated that the three variables that are attitudes, subjective 
norms and behavioral control as a whole explained 57.5 percent of the variance in intention. This explains that another 42.5 percent can be explained by other factors as such nutritional knowledge (Delvarani, Ghazali and Othman, 2013) as well as behavioral beliefs or past behavior (Kim, Kim, Choi \& Ham, 2018). It is perceived by Rahamat (2019) that TPB is one of the theoretical models comprised of elements that include attitudes, subjective norms, behavioural control in which these traits are clarified as well supported and it is a well-supported social psychological theory in forecasting human behaviour.

Table 6: Coefficient Analysis

\begin{tabular}{|c|c|c|c|c|c|}
\hline \multirow[t]{2}{*}{ Model } & \multicolumn{2}{|c|}{$\begin{array}{l}\text { Unstandardized } \\
\text { Coefficients }\end{array}$} & \multirow{2}{*}{$\begin{array}{c}\begin{array}{c}\text { Standardized } \\
\text { Coefficients }\end{array} \\
\text { Beta }\end{array}$} & \multirow[t]{2}{*}{$\begin{array}{ll}T \\
\text { t }\end{array}$} & \multirow[t]{2}{*}{ Sig. } \\
\hline & B & $\begin{array}{l}\text { Std. } \\
\text { Error }\end{array}$ & & & \\
\hline Attitudes & - & 0.087 & -0.174 & - & 0.036 \\
\hline & 0.187 & & & 2.142 & \\
\hline $\begin{array}{l}\text { Subjective } \\
\text { Norms }\end{array}$ & 0.371 & 0.077 & 0.434 & 4.806 & 0.000 \\
\hline $\begin{array}{l}\text { Behavioural } \\
\text { Control }\end{array}$ & 0.462 & 0.094 & 0.466 & 4.914 & 0.000 \\
\hline
\end{tabular}

a. Dependent Variable: ALL_INTENTION

Referring coefficient value of first independent variable that is attitude; $(p=0.036,<0.05)$, it indicates that attitude statistically significant predictor of the intention. It was also found that for second independent variable, the coefficient value of subjective norm is $(p=0.000<0.05)$ is statistically significant thus subjective norm significantly predicted the intention. For the last independent variable that is behavioral control, the coefficient value of 0.462 is statistically significant $(p=0.000<0.05)$. Hence, behavioral control also significantly predicted intention.

Hereby, this study could be claimed that all variables inclusive of attitudes, subjective norms and behavioral control are accepted to have significant effects and relationship with intention. It is also supported by study conducted by Kim, Ham, Yang and Choi (2013) in which findings proved the applicability of the TPB elements; attitudes, subjective norms and behavioural control to research related to consumers' behaviour toward menu labelling in restaurant setting as perceived also by study of Delvarani, Ghazali and Othman (2013) that proved same significant relationship among those TPB Elements excluding additional knowledge variable that was not significant.

Based on results generated in Table 22, beta coefficient value for behavioral control is the highest. With beta value of 0.466 , it indicates that 46.6 percent of the total variation in intention to make use of calories information was influenced by variable of behavioral control. As for subjective norms variable, beta coefficient value of 0.434 designates that 43.4 percent of the total variation in intention would be influenced by subjective norms. Mentioning variable attitude that has beta coefficient value of -0.174 , it specifies that 17.4 percent of intention was negatively influenced by attitude variable. Hence, it is fair to being convicted that behavioral control become the dominant 
INTERNATIONAL JOURNAL OF ACADEMIC RESEARCH IN BUSINESS AND SOCIAL SCIENCES

Vol. 11, No. 13, Beyond 2021 and COVID-19 - New Perspective in the Hospitality \& Tourism Industry. 2021, E-ISSN: 2222-6990 @ 2021 HRMARS

contributor of intention in which subjective norms come second to that influence and attitude as per last.

\section{Conclusion}

In conclusion, this study explicates there is a significant relationship between all independent variables (attitudes, subjective norms and behavioral control) with the dependent variable (intention to make use of calories information). Restaurants' patronage do believe that if they were to equip with knowledge related to practicality of calories information altogether with possible health consequences, that would lead to their positive attitude in making use of it to select for a meal. Is hoped that in order to attain that, restaurateurs may take the initiative to modify menu items by reviewing back their menu calories content to seek lesser calories content menu substitute as there is potential of health-conscious efforts that can encourage healthy eating routine. Block and Roberto (2015) supported that, this slightest effort on food consumption slowly but surely can cause earnest influence on public health. Owing to the fact, restaurants' patronage justified they were still curious to know the calories content of restaurants' menu despite them not being careful with their calories intake.

Realizing the fact that these restaurants' patronage are more influenced with their closest companion and social circle in which they tend to value and choose the least calories content meal suggestions offered by someone they trusted, this should be about time that Malaysian are cautious on what they eat on daily basis to combat obesity and chronic disease problem as the reported amount keep on alarming. It would be overwhelming enough if every health educators, policy makers and foodservice operators specifically should exploit findings of this study in educating public to make use of calories information as their tool in deciding meal selection, not only at restaurants setting but also in home. This fact is confirmed by Radwan, Faroukh and Obaid (2017) in which they reported that fraction of obesity has been increasing to the extent of $52.7 \%$ among individuals that eat out exceeding five times a week due to foods out of home susceptible to be high in total fats, saturated fat including total energy. With smaller steps being taken as a whole, utilizing the calories information may create opportunity among Malaysian citizens to be able practicing healthy eating habit on daily routine.

Despite of having control over own behavior conduct, these restaurants' patronage claimed they would feel confident to make use of calories information as decision guidelines if they were to make healthier calories consumption in a day. The decision is entitled to depend on how hungry they are, the time they had as well as the price of menu items. Aside from that, this aspect of study will considerably benefits future researchers through additional literature and enhanced exposure to restaurants operators through results of socio-demographic earned. Given that majority amount of $35.5 \%(n=27)$ patronage restaurants were not sure about the healthy state of their overall food consumption, campaigns related to this beneficial health information should be elevated solely. It is more worrying that only small percentage of them usually refer calories information on restaurant's menu in conducting meal selection. 
With the perspective from the study, it was found that restaurants' ability to provide calories information were not part of their factors in determining which restaurants to visit, this clearly shows the ignorance and poor realization in the matter of healthy eating habits whereby public refuse to be entertain by health related information. It is even worse that in this day and age, public rely on foods outside from home due to convenience, time constraints and purchasing power, top with the fact that eating these days are pertinent to lifestyle, rather than to consume. Pertaining to that issue, even though availability and awareness owns no guarantee in the perceived usefulness among restaurants' patronage, the likelihood could be escalate as well.

\section{Acknowledgment}

This study was funded by the Ministry of Education Malaysia, Universiti Teknologi MARA, Malaysia (UiTM).

\section{Corresponding Author}

Lovelyna Benedict Jipiu.

Faculty of Hotel \& Tourism Management, Universiti Teknologi MARA, Puncak Alam Campus, 42300 Selangor, Malaysia.

Email: lovely224@uitm.edu.my

\section{References}

Ajzen, I. (1991). The theory of planned behavior. Organizational Behavior and Human Decision Processes, 50, 179-211.

Ajzen, I. (2001). Nature and operation of attitudes. Annual Review of Psychology. https://doi.org/10.1146/annurev.psych.52.1.27

Ajzen, I. (2015). Consumer attitudes and behavior: The Theory of Planned Behavior applied to food consumption decisions. Rivista di Economia Agraria, 121-138.

Ajzen, I., \& Fishbein, M. (1980). Understanding attitudes and predicting social behavior. Prentice-Hall: Englewood Cliffs.

Alam, S., \& Sayuti, S. (2011). Applying the theory of planned behavior (TPB) in halal food purchasing. International Journal of Commerce and Management, 21(1), 8-20. https://doi.org/10.1108/10569211111111676

Ali, N., \& Abdullah, M. A. (2012). The food consumption and eating behaviour of Malaysian urbanites: Issues and concerns. Malaysia Journal of Society and Space, 8(6), 157-165.

Ambak, R., Tupang, L., Hasim, H., \& Salleh, N. (2018). Who do not read and understand food label in Malaysia? findings from a population study. Health Science Journal, 12(1), 1-7. https://doi.org/10.21767/1791-809X.1000548

Armitage, J. C., \& Conner, M. (2001). Efficacy of Theory of Planned Behavior: a Meta Analysis Review. British Journal of Social Psychology.

Banerjee, S., \& Shirley, S. (2019). Applying The Theory of Planned Behavior: Examining how communication, attitudes, social norms, and perceived behavioral control relate to healthy lifestyle intention in Singapore. International Journal of Healthcare Management. https://doi.org/10.1080/20479700.2019.1605687 
INTERNATIONAL JOURNAL OF ACADEMIC RESEARCH IN BUSINESS AND SOCIAL SCIENCES

Vol. 11, No. 13, Beyond 2021 and COVID-19 - New Perspective in the Hospitality \& Tourism Industry. 2021, E-ISSN: $2222-6990$ ๑ 2021 HRMARS

Benton, D., \& Young, H. A. (2017). Reducing calorie intake may not help you lose body weight. $\begin{array}{llll}\text { Perspectives on Psychological 12(5), } & \text { 703-714. }\end{array}$ https://doi.org/10.1177/1745691617690878

Blanding, M. (2011). The yelp factor: Are consumer reviews good for business?. Retrieved from Harvard Business School Working Knowledge: https://hbswk.hbs.edu/item/the-yelp-factorare-consumer-reviews-good-for-business

Block, Condon, Kleinman, Mullen, Linakis, Shiman, \& Gillman. (2013). Consumers' estimation of calorie content at fast food restaurants: cross sectional observational study. NCBI Education.

Block, J., \& Roberto, C. (2015). Potential benefits of calorie labeling on menus. Journal of The American Medical Association, 312(9), 887-888.

Breck, A., Cantor, J., Martinez, O., \& Elbel, B. (2014, October 1). Who reports noticing and using calorie information posted on fast food restaurant menus? 30-36. https://doi.org/10.1016/j.appet.2014.05.027

Butler, S. (2018). The impact of menu labeling on food choices of consumers. ProQuest.

Chahal, D. K., \& Kamil, N. M. (2017). The determinants of customer satisfaction and behavioral intention among restaurants in Klang Valley area of Malaysia: A conceptual study. Journal of Social Science \& Humanities, 12(2), 307-317.

Cohen, J. (1992). Quantitative methods in psychology: A power primer. Psychological Bulletin, 112(1), 155-159.

Daghbashyan, Z. (2013). Essays on University Efficiency Analysis and Entrepreneurship Among University Graduates. Department of Industrial Economics and Management, Royal Institute of Technology.

Delvarani, S., Ghazali, H., \& Othman, M. (2013). Factors affecting fast food consumers' intention to use menu labeling in Klang Valley, Malaysia. International Food Research Journal, 20(4), 17991805.

Din, N., Shariff, S. M., \& Zahari, M. S. (2017). Nutritional labelling in Malaysian full service restaurant menu. https://doi.org/10.21834/jabs.v2i2.178

Etikan, I., Musa, S. A., \& Alkassim, R. S. (2016). Comparison of convenience sampling and purposive sampling. American Journal of Theoretical and Applied Statistics, 5(1), 1-4. https://doi.org/10.11648/j.ajtas.20160501.11

Foodservice Profile - Malaysia July 2014. (2014). Retrieved March 21, 2018, from Agriculture and AgriFood Canada: http://www.agr.gc.ca/eng/industry-markets-and-trade/international-agri-foodmarket-intelligence/asia/market-intelligence/foodservice-profilemalaysia/?id=1418754135558

Green, J., Brown, A., \& Vachaspati, P. (2014). Sociodemographic disparities among fast-food restaurant customers who notice and use calorie menu labels. Journal of The Academy of Nutrition and Dietitics, 2212-2672.

Hassan, H., Sade, A. B., \& Rahman, M. S. (2018). Obesity and overweight issues could undermine malaysia's competitiveness. International Journal of Human Rights in Healthcare. https://doi.org/10.1108/IJHRH-09-2017-0050

Ismail, A. (2018). How many calories should i eat a day? Research Gate. Retrieved from https://www.researchgate.net/publication/324943266 
Jager, W. (2000). Modelling consumer behaviour. PhD Thesis: Centre for Environmental and Traffic Psychology. Retrieved from http://www.rug.nl/research/portal

Jun, J., \& Arendt, S. (2016). Understanding healthy eating behaviors at casual dining restaurants using the extended Theory of Planned Behavior. International Journal of Hospitality Management, 106-115. https://doi.org/10.1016/j.ijhm.2015.12.002

Kholoud, I. (2009). Analyzing The use of UTAUT Model in explaining an online behaviour: Internet banking adoption. Ph.D. Dissertation, Department of Marketing and Branding, Brunei.

Kim, E., Ham, S., Yang, S., \& Choi, J. G. (2013). The roles of attitude, subjective norm, and perceived behavioral control in the formation of consumers' behavioral intentions to read menu labels in the restaurant industry. International Journal of Hospitality Management, 203-213. https://doi.org/10.1016/j.ijhm.2013.06.008

Kim, H., Kim, Y., Choi, H., \& Ham, S. (2018). Relationships among behavioral beliefs, past behaviors, attitudes and behavioral intentions toward healthy menu selection. Nutrition Research and Practice 2018, 2(4), 348-354.

Kim, M. J., Kim, K. W., \& Lim, H. J. (2015). Factors associated with nutrition label use among female college students applying The Theory of Planned Behavior. Nutrition Research and Practice, 9(1), 63-70. https://doi.org/10.4162/nrp.2015.9.1.63

Kiszko, Martinez, Abrams, \& Elbel. (2014). The influence of calorie labeling on food orders and consumption: A review of the literature. Journal of Community Health: NYU Scholar.

Kitchlu, N., Khan, S., Shahlaei, M., \& Vukmirovic, M. (2018). Assessing the effectiveness of calorie labeling on restaurant menus. Environ. Health Rev, 56(3), 73-82. https://doi.org/10.5864/d2013-025

Kwan, S., Pan, L., Maynard, L., McGuire, L., \& Park, S. (2016). Factors associated with self-reported menu labeling use among US adults. HHS Public Access, 116(7), 1127-1135. https://doi.org/10.1016/j.jand.2015.12.015.

Lee, S. (2013). Understanding customers' healthy eating behavior in restaurants using the health belief model and Theory of Planned Behavior. Dissertation of Hospitality and Tourism Management, Virginia Tech.

Lee, S., Lee, K. S., Chua, B., \& Han, H. (2017). Independent café entrepreneurships in Klang Valley Malaysia - Challenges and critical factors for success: Does family matter?. Journal of Destination Marketing \& Management, 363-374.

Malaysians Consume 500-700 Extra Calories a Day, Says Health Minister. (2013, October 28). Retrieved from Malay Mail Website:

https://www.malaymail.com/news/malaysia/2013/10/28/malaysians-consume-500-700-

extra-calories-a-day-says-health-minister/551703

Mills, J., \& Thomas, L. (2008). Assessing customer expectations of information provided on restaurant menus: A confirmatory factor analysis approach. Journal of Hospitality \& Tourism Research, 32(1), 62-88. https://doi.org/10.1177/1096348007309569

Nor, M. N., Noor, A. N., Ahmad, Z., Khalid, S. A., \& Ibrahim, I. I. (2017). Factors affecting turnover intention among Gen $\mathrm{Y}$ in hotel industry. Jurnal Intelek, 12(1), 1-5.

Petre, A. (2019). Does 'calories in vs. calories out' really matter? Retrieved from Healthline Website: https://www.healthline.com/nutrition/calories-in-calories-out\#what-it-is 
Radwan, H., Faroukh, E., \& Shaker, R. (2017). Menu labeling implementation in dine-in restaurants: The public's knowledge, attitude \& practices. Archives of Public Health, 75(8). https://doi.org/10.1186/s13690-017-0177-9

Rahamat, S. (2019). Influence of Malaysian consumers' intentions and use of menu labeling on purchase behavior. lowa State University Capstones, Theses and Dissertations.

Ramayah, T., Lee, J. W., \& Lim, S. (2012). Sustaining the environment through recycling: an empirical study. Journal of Environmental Management. https://doi.org/10.1016/j.jenvman.2012.02.025

Restrepo, B., Minor, T., \& Peckham, J. (2018). The association between restaurant menu label use and caloric intake. Economic.

Rettner, R. (2013). Fast food: Meals have more calories than you think. Retrieved from LiveScience Health Web Site: https://www.livescience.com/41200-calorie-underestimate-subway.html

Roscoe, J. T. (1975). Fundamental research statistics for the behavioral sciences. New York: Rinehart and Winston.

Sekaran, U., \& Bougie, R. (2013). Research methods for business: A skill-building approach (6th ed.). New York: John Wiley \& Sons. Retrieved March 22, 2018.

Sekaran, U., \& Bougie, R. (2016). Research methods for business: A skill building approach (7th ed.). New York: John Wiley \& Sons. Retrieved October 20, 2017.

Stern, P. C. (2005). Understanding individuals' environmentally significant behavior. Environ. Law. Rep. News Anal, 10785-10790.

Stran, K. (2013). An evaluation of the intention college students to utilize calorie labelling in fast food and full service restaurant. Department of Health Science Graduate School of The University Alabama.

Stran, K., Knol, L., Severt, K., \& Lawrence, J. (2016). College students' intentions to use calorie information on a restaurant menu: Application of the Theory of Planned Behavior. American Journal of Health Education, 215-223. Retrieved from http://www.tandfonline.com/loi/ujhe20

Sturm, R., Huang, H., Tsang, F., Hiatt, L., Smart, R., Wright, C., \& Wu, H. (2018). Examining consumer responses to calorie information on restaurant menus in a discrete choice experiment. 111.

Sun, X. (2018). Consumer's preferences among low-calorie food alternatives in casual dining restaurants. Purdue University Graduate School Thesis. School of Hospitality \& Tourism Management. https://doi.org/10.25394/PGS.7541978.v1

Tabachnick, B. G., \& Fidell, L. S. (2013). Using multivariate statistics. United State of America: Pearson Education, Inc.

Tan, C. (2014). More Malaysians eat out nowadays but are we eating enough healthy food? Retrieved from The Star Online Website: https://www.thestar.com.my/news/nation/2014/08/03/food-always-on-our-minds-moremalaysians-eat-out-nowadays-but-are-we-eating-enough-healthy-food/

Vijayakumaran, R. K., \& Nur, A. S. (2018). Influences of nutrition information on fast food consumption among undergraduates. Food Research, 2(3), 228-233. https://doi.org/10.26656/fr.2017.2(3).288

Zainol, Z., Yahaya, R., Osman, J., Omar, N. A., Ramdan, M. R., \& Habidin, N. F. (2018). The role of nutrition label among Malaysian consumer: A preliminary review. International Journal of 
INTERNATIONAL JOURNAL OF ACADEMIC RESEARCH IN BUSINESS AND SOCIAL SCIENCES

Vol. 11, No. 13, Beyond 2021 and COVID-19 - New Perspective in the Hospitality \& Tourism Industry. 2021, E-ISSN: $2222-6990$ @ 2021 HRMARS

Academic Research in Business and Social Sciences, 8(4), 1058-1073. https://doi.org/10.6007/IJARBSS/v8-i4/4143 